\title{
Spontaneous pneumomediastinum secondary to acute stress reaction: a case report
}

\author{
Pneumomediastino espontâneo secundário a reação aguda ao estresse: um relato de caso \\ Neumomediastino espontáneo secundario a reacción aguda al estrés: reporte de un caso \\ José Gabriel Miranda da Paixão ${ }^{1 *}$, Alcyr Luis de Miranda Araujo ${ }^{1}$, Amanda Chagas Barreto², Vinícius \\ Fialho Teixeira ${ }^{3}$.
}

\begin{abstract}
Objective: As spontaneous pneumomediastinum (PMS) is a rare and idiopathic entity, the present report proposes to record one of the few cases of a patient who presented PMS after intense cries induced by psychiatric illness. Case details: A 50-year-old male patient who was admitted to emergency department with agitation, cold sweating, tachycardia and echolalia, associated with screams. Symptoms lasted for about 15 hours and they have started after the patient witnessed a first-degree relative (father) dying at home due to COVID-19. A thorax computed tomography scan found a Pneumomediastinum that involved the upper mediastinum with mild extension to lower neck, near the Thyroid gland. After acute stress reaction diagnosis, accordingly with DSM-IV criteria, patient followed observation for two days and punctual benzodiazepines use, having no clinical complications during hospital stay. Pneumomediastinum was completely resolved. Final considerations: Screams motivated by psychiatric condition can be added to SPM causes list and should motivate phisician awareness, since it may bare life-threatening complications associated.
\end{abstract}

Keywords: Mediastinal emphysema, Tomography, Emergencies, Mental disorders.

\section{RESUMO}

Objetivo: Registrar um dos poucos casos de um paciente que apresentou SPM após gritos intensos induzidos por afecção psiquiátrica. Detalhamento do caso: Paciente do sexo masculino, 50 anos, admitido no pronto-socorro com agitação, sudorese fria, taquicardia e ecolalia, associado a gritos. Os sintomas duraram cerca de 15 horas e começaram após o paciente testemunhar um parente de primeiro grau (pai) morrendo em casa devido ao COVID19. Uma tomografia computadorizada do tórax encontrou um pneumomediastino que acometeu o mediastino superior com pequena extensão para a porção inferior do pescoço, próximo à glândula tireóide. Após o diagnóstico de reação aguda ao estresse, de acordo com os critérios do DSM-IV, o paciente seguiu a observação por dois dias e o uso pontual de benzodiazepínicos, sem complicações clínicas durante a internação. O pneumomediastino foi completamente reabsorvido. Considerações finais: Gritos motivados por condição psiquiátrica podem ser adicionados à lista de causas de SPM e tal situação merece a atenção do médico, uma vez que pode apresentar complicações potencialmente fatais associadas.

Palavras-chave: Enfisema mediastínico, Tomografia, Emergência, Transtornos mentais.

\section{RESUMEN}

Objetivo: Dado que el neumomediastino espontáneo (SPM) es una entidad rara e idiopática, el presente informe propone registrar uno de los pocos casos de un paciente que presentó SPM después de fuertes gritos inducidos por una enfermedad psiquiátrica. Detalles del caso: paciente masculino de 50 años que ingresó en departamento de emergencia con agitación, sudoración fría, taquicardia y ecolalia, asociado a gritos. Los síntomas duraron aproximadamente 15 horas y comenzaron después de que el paciente presenciara la muerte de un familiar de primer grado (padre) en su hogar debido a COVID-19. Una tomografía computarizada de tórax encontró un neumomediastino que afectó el mediastino superior con una extensión leve a la parte inferior del cuello, cerca de la glándula tiroides. Después del diagnóstico de reacción aguda al estrés, de acuerdo con los criterios del DSM-IV, el paciente siguió la observación durante dos días y el uso puntual de benzodiacepinas, sin complicaciones clínicas durante la internación hospitalaria. El neumomediastino se resolvió por completo. Consideraciones finales: Los gritos motivados por una condición psiquiátrica se pueden agregar a la lista de causas de SPM y deben motivar la conciencia de los médicos, ya que pueden mostrar complicaciones potencialmente fatales asociadas.

Palabras clave: Enfisema mediastínico, Tomografía, Urgencias médicas, Transtornos mentales.

\footnotetext{
${ }^{1}$ Mario Pinotti Municipal Hospital, Belém - PA. *E-mail: gabrielpaixao@msn.com

${ }^{2}$ Centro Universitário Metropolitano da Amazônia (FAMAZ), Belém - PA.

${ }^{3}$ Universidade do Estado do Pará (UEPA), Belém - PA.
} 


\section{INTRODUCTION}

Spontaneous pneumomediastinum (SPM) is a rare and idiopathic entity (GRAPATSAS K, et al.,2018). First described by René Laennec in the $19^{\text {th }}$ century, it is associated with several underlying diseases such as asthma, interstitial lung disease, pulmonary emphysema and bronchiectasis, in addition there are cases caused as a result of vomiting and barotrauma (SINGLA M, et al,2012; IYER VN, et al.,2009; SLAUGHTER JM e ROPPOLO L,2017).

SPM is defined as a benign, self-limited condition that may or may not be recurrent (ABOLNIK I, et al.,1991; JANJUA FR, et al., 2014). Its pathophysiology is explained as alveolar rupture after forced expiration against a closed glottis that allows air to migrate from alveoli to interstitium, resulting in dissection towards pulmonary hilum and mediastinum, following the pulmonary vasculature path (IYER VN, et al.,2009; MIHOS P, et al., 2004; ABOLNIK I, et al.,1991; JANJUA FR, et al., 2014). This mechanism is called the Mackling Effect (GRAPATSAS K, et al.,2018; JÚNIOR LGC, et al., 2016).

Most patients diagnosed with SPM have two features in common: they are in previously good health and have recently experienced airway obstruction, such obstruction being predominantly acute, transient and recurrent (MUNSELL W, 1967).

The main clinical complaint manifested is chest pain, associated with dyspnea, however asymptomatic cases can occur (IRWIN T et al., 2017; MOHAMED W et al., 2019). Physical examination and complementary imaging exams show subcutaneous emphysema in cervical region, pneumothorax and Hamman's sign. The latter, commonly reported as pathognomonic for SPM, is not always present at first medical evaluation (DAJER-FADEL W, et al., 2013).

An incidence between 1: 800 and 1: 42,000 is reported, and men are more likely to be affected than women in most studies (ABOLNIK I, et al.,1991; CACERES M, et al.,2008; PERNA V, et al.,2010). As much as 32\% of SPMs may have concomitant pneumothorax and predisposing factors may be present in $20 \%-80 \%$ of patients (IYER VN, et al.,2009; CACERES M, et al.,2008).

There are well-documented causes for this condition, such as vomiting, asthma exacerbation, passing stool, childbirth labor and stenuous physical exercise (MIHOS P, et al., 2004). Unusual causes such as balloon filling, playing instruments and intense screaming are also evidenced in sparse reports, but $32 \%$ to $44 \%$ of cases have no defined cause and can be considered idiopatic (ITO S, et al.,1989 ; SINGLA M, et al.,2012; CACERES M, et al.,2008; HIRAYAMA I, et al.,2016; DAJER-FADEL W, et al., 2013).

Screaming related cases are uncommon and associated with different situations such as yelling at marines recruits during military activity, forceful screaming during pop concerts, screaming during roller coaster ride and after singing performance (SINGLA M, et al.,2012; SLAUGHTER JM e ROPPOLO L., 2017; JANJUA FR, et al.,2014; SHINE NP, et al..2005).

Although psichiatric conditions are related to SPM in recent literature, most of reports describes intense vomiting crisis and drug abuse as leading cause in those patients (ÖNAL O, et al., 2015; HOCHLEHNERT A, et al., 2010). Therefore, the present report is one of the few reported cases of a patient who presented spontaneous pneumomediastinum after intense screaming induced by psychiatric condition.

\section{CASE REPORT}

A 50-year-old male patient who was admitted to emergency department with agitation, cold sweating, tachycardia and echolalia, associated with intense screaming. Symptoms lasted for about 15 hours and they have started after the patient witnessed a first-degree relative (father) dying at home due to COVID-19. There were no comorbidities or history of head trauma, nor any psychotropic or illicit drug use.

Physical examination revealed tachypnea, tachycardia, sweating, mental confusion and disorientation. Face, neck, chest and abdomen palpation and inspection showed no alteration. Pulmonary auscultation was normal, whereas cardiac auscultation showed hypophonetic sounds and crepitus heard with the heartbeat (Hamman's Sign). Blood pressure was $135 \times 90 \mathrm{mmHg}$, oxygen saturation $98 \%$, in ambient air and body temperature $36,7^{0}$. Glasgow Coma Scale assessment was E4V4M5. 
After initial care, routine laboratory tests took place, including serum tests for benzodiazepines, opiates, alcohol and amphetamines. After blood sample collection, standard benzodiazepine was administered intramuscularly.

Two hours after entering emergency department, with controlled acute psychiaric symptoms, clinical reassessment was carried out showing a communicative, calm and disoriented patient, maintaining good oxygen saturation, blood pressure $129 \times 84 \mathrm{mmHg}$ and absence of changes on physical examination (except for Hamman's sign).

Laboratory tests showed normal blood count, coagulogram, urea, creatinine, sodium, potassium and glycemia, as well as none of the tested drugs were positive in patient's serum. A skull, neck and thorax computed tomography (CT) scan found a Pneumomediastinum that dissected the upper mediastinum with mild extension to lower neck, near the Thyroid gland. No injury, nor impacted foreign body in trachea, esophagus, carina, right or left bronchi were found (Figure 1).

Then, the patient was put under oxygen mask ( $3 \mathrm{~L} /$ minute) and a barium esophagogram was performed. Like others complementary image exams performed, it found no signs of esophageal perforation. The oxygen supply under mask was maintained for 6 hours after admission, while regular oral diet was provided 12 hours after admission. During hospital stay, there was a proper clinical follow up by head and neck surgeon.

Psychiatric consultation was taken during the observation period, after which an acute reaction to stress diagnosis was made under DSM-IV criteria, taking ito consideration, as triggering event, the witnessing of a family member death at home, during COVID-19 pandemic, culminating in uncontrolled screaming for about 15 hours.

The patient underwent observation for three days with punctual benzodiazepines use, having no clinical complications during hospitalization. Pneumomediastinum was completely resolved on revision CT scan and hospital discharge was made with advices for psychological and psychiatric follow-up, as well as follow-up consultation with head and neck surgeon on an outpatient basis (Figure 2).

Figure 1 - Pneumomediastinum evidence in admission CT-scan.
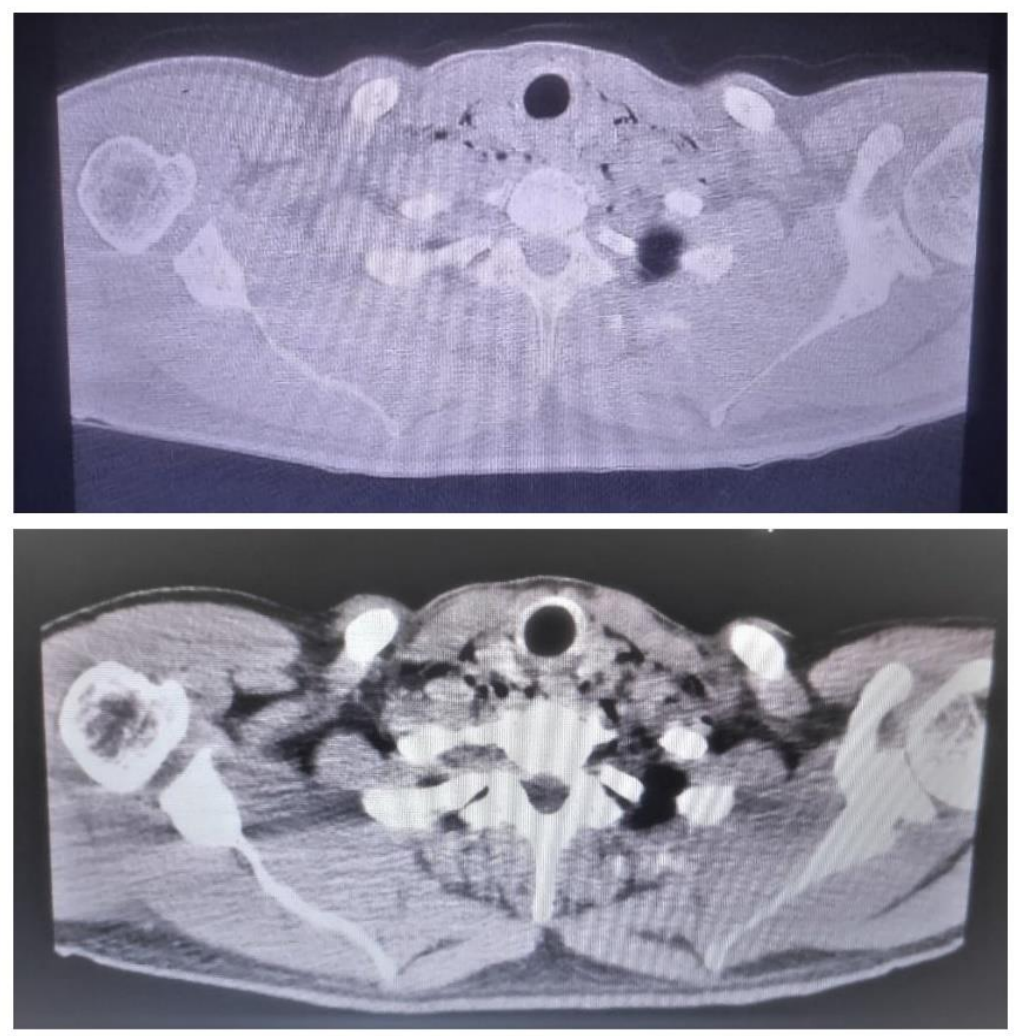

Source: Paixão JGM, et al., 2020. 


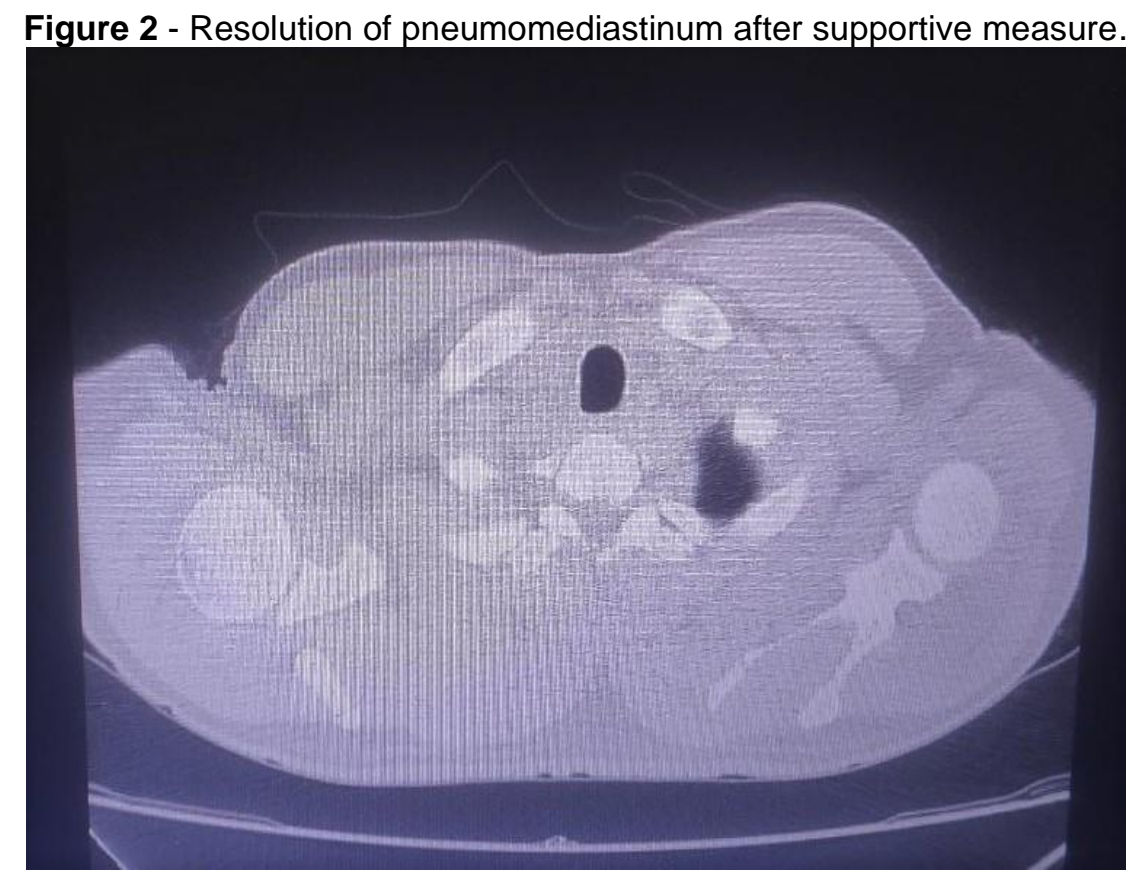

Source: Paixão JGM, et al., 2020.

\section{DISCUSSION}

SPM is rare in emergence department. It was described in 1939 by Luis Harmman through a case series, although it has been known since the $19^{\text {th }}$ century by René Laennec's reports (GRAPATSAS K, et al.,2018; MIHOS P, et al., 2004; SINGLA M, et al.,2012).

Its physiopathologic process was described by Macklin CC (1939) and Macklin CC and Mackling MT (1944), after animal experiments and further application of results on clinical observations, in an attempt to bring physicians to know how to differenciate cases that may have worst prognosis.

Among most common causes in the literature, 32\% to $44 \%$ are idiopathic (SINGLA M, et al., 2012; CACERES M, et al., 2008; HIRAYAMA I, et al., 2016; DAJER-FADEL W, et al., 2013). Cases originating from intense screaming respond for $1.5 \%$, according to Dajer-Fadel W et al (2013), and are usually compared with those not associated with diseases, such as playing musical instruments, singing, lifting weights, prolonged screaming during work or music concerts.

Psychiatric conditions can also cause situations in wich Mackling Effect are likely to happen, as intense vomiting, due to anorexia and drug abuse, and intense breathing manoeuvres during smoking both causing some sort of barotrauma (ÖNAL O, et al., 2015; HOCHLEHNERT A, et al., 2010; WEISS ZF, et al., 2019). In the present case, an acute stress reaction leaded to a intense shouting for more than 12 hours, wich certainly contributed to SPM onset.

After initial care, it was suspected that the patient might have cardiopulmonary changes that justified confusion and disorientation. Although Hamman's Sign is considered pathognomonic for SPM, the possibility of COVID-19 was raised due to recent contact with an infected individual (father).

It was not possible to test the pacient for exlcusion of Severe Acute Respiratory Syndrome coronavirus 2 (SARS-CoV-2), due to de lack of assay kit. Considering that image changes may precede respiratory symptoms, a chest tomography was suitable for ruling it out any pulmonary infectious condition (KIM, JY, et al.,2020).

Imaging exam ended up showing a rare finding described by the authors. Even though there are COVID19 cases related to SPM, our patient had no coughing clinical history, what, after thorax CT scan, helped to rule out associated viral pneumonia (JANSSEN J, et al., 2020; WANG J, et al.,2020; ZHOU C, et al., 2020). 
According to most case series in the literature, the most common clinical sign in pneumomediastinum is chest pain present in 34\% to 88\% of cases (MUNSELL W, 1967; ABOLNIK I, et al.,1991; MACIA I, etal., 2007; CACERES M, et al.,2008; PERNA V, et al.,2010; DAJER-FADEL W, et al., 2013; GRAPATSAS K, et al.,2018). After chest pain, the most frequent symptoms are: dyspnoea (from $39 \%$ to $61 \%$ ), odynophagia / dysphagia (from $4 \%$ to $49 \%$ ) and coughing (from $20 \%$ to $32 \%$ ).

However, in the case presented, none of these symptoms were present and diagnosis was guided by Hamman's Sign, evidenced in physical examination at emergency room. This sign is shown in $12 \%$ to $64 \%$ of cases, but, as it is pathognomonic, it should be valued if it appears on physical examination and SPM diagnosis must be worked out through imaging exams, in a manner similar to that described in Thakeria P et al ( 2019) and Alexandre AR et al (2018) in the management of a patient with no symptoms and whose only clinical sign was Hamman's Sign.

Considering the most common symptom, it is not surprising that SPM is quite underdiagnosed among patients with chest pain and it is commonly an incidental finding during medical investigations, wich are directed towards more common causes of this symptom.

In addition, when supportive measures usually are enough for clinical recovery, further investigation are left in second plan, either by physician, by patient or even by both of them. The management adopted for the patient in this report was based on algorithms proposed by Dajer-Fadel W (2013) and Newcomb AE and Clarke CP (2005), as well as observation time of three days was chosen because it was the same adopted for patients with similar pathophysiology and clinical evolution by other authors in similar situations (HOCHLEHNERT A, et al., 2010; SWAMINATHAN N, et al., 2019).

As many rare diseases, there are lots of difficulties in developing studies to define treatments. Apart from previously mentioned algorithms, attempts to standardize treatment for SPM are scarce in the literature. We can highlight, at most, case series reporting institutional experience that ended up becoming a standard (MUNSELL W, 1967; ABOLNIK I, et al., 1991; MIHOS P, et al., 2004; MACIA I, etal., 2007; CACERES M, et al., 2008;).

In general, treatment and management must follow: supply of inhaled oxygen, pain control, bedrest, zero oral intake and radiological control. Expectating on patients buys time to allow the organism to re-absorb emphysema, avoid and / or control triggering factors and, when suitable for the case, exclude esophageal perforation. In addition, as most patients with SPM do not have a history of airway instrumentation, pleural effusion or vomiting, they most commonly do not have damage to mediastinal organs, a fact that avoids the use of intravenous antibiotics and the need for invasive procedures, by these means reducing hospitalization (BANKI F, et al., 2013).

Psychotic behaviors or an acute reaction to stress can favor actions that mimic the Valsalva Maneuver (SWE T, et al.,2016). The classical Munsell et al (1967) review highlighted as much as $15 \%$ of patients with psychiatric disorders and there are plenty of examples of published cases demonstrating how those disorders can influence SPM onset (SWE T, et al.,2016; HOCHLEHNERT A, et al., 2010; ÖNAL O, et al., 2015; WEISS ZF, et al., 2019).

Acute stress reaction is defined in DSM-IV as a disorder that follows experiencing, witnessing, or being confronted with events involving actual or threatened death, physical injury, or other threats to the physical integrity of the self or others and its symptons include sweating, heart palpitations, shaking, chest and abdomen symptoms (e.g. difficulty in breathing, feeling of choking or chest pain), brain and mind symptoms (e.g. feeling dizzy, feeling that objects are unreal or fear of dying), general syptoms (as numbness or chills), muscle and mental tension symptoms and other non-specific symptoms, for example being easily startled, difficulty concentrating or irritability (BREWIN CR, et al., 1999).

In moderate or severe cases, one may also exhibit despair or hopelessness, disorientation, withdrawal from social activities, decreased attention, aggression or over-activity). Some of this symptons, like mental confusion and sweating, were experienced by our patient and it is noteworthy that some of them can be mistaken by other emergency room cause, including SPM. Thus optimal medications and management of these conditions should be performed, including patient and family /caregivers information. 
The authors reiterate the need for further systematic reviews to define clear conduct in cases of SPM, although a personalized protocol is more effective according to each institution's epidemiological profile. In addition, the correct anamnesis and detailed physical examination cannot fail to be the mainstay to guide diagnostic procedures wich will lead to appropriate therapies.

Among all unusual situations that lead to this condition, psychiatric disorders should be observed in terms of duration and features, as they can lead to behaviors and attitudes that stimulate Valsalva Maneuver and favor Macklin effect occurrence.

In the case described, a screaming crisis of more than 15 hours was the precipitating factor, a situation that does not present a similar described in the literature until today. Therefore, the authors suggest that screams motivated by a psychiatric condition can be added to SPM causes list and should motivate phisician awareness in those emergency situations, since it may bare life-threatening complications associated.

\section{REFERENCES}

1. ABOLNIK I, et al. Spontaneous pneumomediastinum: a report of 25 cases. Chest. 1991;100(1): 93-95.

2. ALEXANDRE AR, et al. Hamman's crunch: a forgotten clue to the diagnosis of spontaneous pneumomediastinum. BMJ Case Reports. 2018; 2018 (1):99.

3. BANKI F, et al. Pneumomediastinum: etiology and a guide to diagnosis and treatment. The American Journal of Surgery. 2013; 206(6): 1001-1006.

4. BREWIN CR, et al. Acute stress disorder and posttraumatic stress disorder in victims of violent crime. American Journal of Psychiatry. 1999; 156(3): 360-366.

5. CACERES M, et al. Spontaneous pneumomediastinum: a comparative study and review of the literature. The Ann Thorac Surg.2008; 86(3): 962-966.

6. DAJER-FADEL W. et al. Systematic review of spontaneous pneumomediastinum: a survey of 22 years' data. Asian Cardiovascular and Thoracic Annal. 2014; 22(8): 997-1002.

7. GRAPATSAS K, et al. Hamman's syndrome (spontaneous pneumomediastinum presenting as subcutaneous emphysema): A rare case of the emergency department and review of the literature. Respiratory medicine case reports. 2018; 23: 63-65.

8. HIRAYAMA I, et al. Hamman syndrome: pneumomediastinum combined with hyperosmolar hyperglycemic state. Am J Emerg Med. 2016; 34(10): 2058.

9. HOCHLEHNERT A, et al. Spontaneous pneumomediastinum in anorexia nervosa: a case report and review of the literature on pneumomediastinum and pneumothorax. European Eating Disorders Review: The Professional Journal of the Eating Disorders Association. 2010; 18(2):107-115.

10. ITO S, et al. A case of spontaneous pneumomediastinum in a trombonist. Kokyu to junkan. 1989; 37(12): 1359.

11. IRWIN T, et al. A peculiar case of asymptomatic spontaneous pneumomediastinum. Respiratory medicine case reports. 2017; 22: 228-231.

12. IYER VN, et al. Spontaneous pneumomediastinum: analysis of 62 consecutive adult patients. Mayo Clin Proc. 2009; 84(5): 417-421.

13. JANJUA FR, et al. Pneumomediastinum After Riding A Roller Coaster. Am J Respir Crit Care Med. $2014 ; 189: 1$.

14. JANSSEN J, et al. Spontaneous pneumomediastinum in a male adult with COVID-19 pneumonia. The American Journal of Emergency Medicine. 2020; 34(3): 356-360.

15. JÚNIOR LGC, et al. Spontaneous pneumomediastinum, Hamman syndrome: case report. Medicina (Ribeirão Preto. Online). 2016; 49(6): 574-577.

16. KIM, JY, et al. The first case of 2019 novel coronavirus pneumonia imported into Korea from Wuhan, China: implication for infection prevention and control measures. J Korean Med Sci. 2020; 35(5).

17. MACIA I, et al. Spontaneous pneumomediastinum: 41 cases. European journal of Cardio-thoracic surgery. 2007; 31(6): 1110-1114.

18. MACKLIN CC. Transport of air along sheaths of pulmonic blood vessels from alveoli to mediastinum: clinical implications. Archives of Internal Medicine. 1939; 64(5): 913-926.

19. MACKLIN MT, MACKLIN CC. Malignant interstitial emphysema of the lungs and mediastinum as an important occult complication in many respiratory diseases and other conditions: an interpretation of the clinical literature in the light of laboratory experiment. Medicine. 1944; 23(4): 281-358.

20. MIHOS P, et al. Sports-related spontaneous pneumomediastinum. Ann Thorac Surg. 2004; 78(3): $983-986$.

21. MOHAMED W, et al. Spontaneous pneumomediastinum (Hamman's syndrome): presenting as acute severe asthma. JR Coll Physicians Edinb. 2019; 49: 31-33.

22. MUNSELL WP. Pneumomediastinum: a report of 28 cases and review of the literature. Jama. 1967; 202(8): 689-693.

23. NEWCOMB AE, CLARKE CP. Spontaneous pneumomediastinum: a benign curiosity or a significant problem? Chest. 2005;128(5): 3298-3302.

24. ÖNAL Ö, et al. A Rare Cause of Spontaneous Pneumomediastinum: Ecstasy Ingestion. Turkish thoracic journal. 2015; 16(4): 198. 
25. PERNA V, et al. Pneumomediastinum: is this really a benign entity? When it can be considered as spontaneous? Our experience in 47 adult patients. Eur J Cardio-thorac. 2010; 37(3): 573-575.

26. SHINE NP, et al. Spontaneous retropharyngeal and cervical emphysema: a rare singer's injury.Ear, nose \& throat journal. 2005; 84(11): 726-727.

27. SINGLA M, et al. Ooh-rah! an unusual cause of spontaneous pneumomediastinum. Military medicine. 2012;177(11): 1396-1398.

28. SLAUGHTER JM, ROPPOLO L. "Screaming your Lungs Out!" A Case of Boy Band-Induced Pneumothorax, Pneumomediastinum, and Pneumoretropharyngeum. J Emerg Med. 2017;53(5): 762-764.

29. SWAMINATHAN N, et al. Pneumomediastinum in a Heavy Weightlifter. European journal of case reports in internal medicine. 2019; 6(5).

30. SWE T, et al. Spontaneous pneumomediastinum, pneumoretroperitoneum, and cervicofacial subcutaneous emphysema after repeatedly and forcefully blowing into a bottle. J Community Hosp Intern Med Perspect. 2016; 6(6): 33361.

31. THAKERIA P, et al. Smartphone aiding in analysis of Hamman's sign. BMJ Case Reports CP. $2019 ; 12(11): 9$.

32. WANG J, et al. Spontaneous pneumomediastinum: a probable unusual complication of coronavirus disease 2019 (COVID-19) pneumonia. Korean Journal of Radiology. 2020; 21(5): 627.

33. WEISS ZF, et al. Pneumomediastinum in marijuana users: a retrospective review of 14 cases. BMJ open respiratory research. 2019; 6(1).

34. ZHOU C, et al. COVID-19 with spontaneous pneumomediastinum. The Lancet Infectious Diseases. 2020; 20(4): 510. 